\title{
Effect of Textile Waste Water on Seed Germination and Some Physiological Parameters in Vegetable Crop under Drip Irrigation
}

\author{
Manpreet Kaur*, Vikas Sharma, Yadvendra Pal Singh and V.D. Paradkar \\ ${ }^{1}$ Department of Textiles and Apparel Designing, ${ }^{2}$ Department of Soil and Water Engineering, \\ Maharana Pratap University of Agricultural and Technology \\ Udaipur, Rajasthan - 313001, India \\ *Corresponding author
}

\section{A B S T R A C T}

The use of industrial waste water for irrigation through drip system has emerged a very important way to utilize its nutrients and removal of its pollutants load by cultivating

\section{Keywords}

Textile waste water, Drip irrigation, Effluent, Vegetable crop

Article Info

Accepted:

15 June 2019

Available Online:

10 July 2019 various crops (tomato, brinjal). An experiment was conducted to evaluate the impact of textile factory effluents $(0,10,35,75$ and $100 \%$ concentration) on germination and some physiological parameters like biomass production, root development in vegetable crop. Plants were raised in small pots in triplicate and irrigated with various concentrations $(0$, $10,35,75$ and $100 \%$ ) of effluent. Germination \%, biomass production and various attributes of root development were determined in plants grown under different treatments. Plants exhibited a reduction in percentage germination, root and shoot dry weight, number of root branches/plants grown with higher concentration (75 and 100\% concentration) of textile effluents. However, the effect of textile effluents was promotive rather than inhibitory on these parameters when applied in low concentrations (10 and 35\%). It was concluded that the effect of textile effluent was crop specific depending on the concentration and stage of growth. It was suggested that waste water from textile industry could be utilized for irrigation purposes through drip irrigation after proper treatment and may contribute, at least in part towards solving the problem of disposal of textile effluent.

\section{Introduction}

The continued population growth, increased per capital water consumption and increase water requirements for industry and irrigation have also resulted in considerable decrease of usable water resources (Naddafi et al., 2005). In this view of this scenario, there is an imperative need to exploit non-conventional resources to meet the irrigation water demand.

\section{Materials and Methods}

\section{Experimental details}

In this study plastic pots of size $(15 \mathrm{~cm} \times 15$ $\mathrm{cm})$ were filled with $2 \mathrm{~kg}$ of sandy loam soil and five seed of tomato and brinjal were sown separately after proper seed treatment. A lateral pipe of $16 \mathrm{~mm}$ diameter having $2 \mathrm{lph}$ discharge inline emitter with $45 \mathrm{~cm}$ spacing 
was laid on both line of plastic plot. Drip irrigation was used to irrigate the soil on visual basis. The observations from both crops were taken to evaluate the impact of textile factory effluents $(0,10,35,75$ and $100 \%$ concentration) on germination and some physiological parameters like biomass production, root development.

\section{Treatment details}

$\mathrm{T}_{1}-$ Textile industry effluents with $0 \%$ concentration

$\mathrm{T}_{2}$ - Textile industry effluents with $10 \%$ concentration

$\mathrm{T}_{3}$ - Textile industry effluents with $35 \%$ concentration

$\mathrm{T}_{4}$ - Textile industry effluents with $75 \%$ concentration

$\mathrm{T}_{5}-$ Textile industry effluents with $100 \%$ concentration

\section{Results and Discussion}

The result in Table 1 found that the significant impact of textile factory effluents
$(0,10,35,75$ and $100 \%$ concentration) on germination and some physiological parameters like biomass production root development for tomato and brinjal crop under different treatment. The percentage germination was found to be highest in treatment $\mathrm{T}_{1}$ with a value of $85 \%$.The biomass parameters such as dry weight of root and dry weight of shoot were found highest under treatment $\mathrm{T}_{3}$ (Textile industry effluents with $35 \%$ concentration) with values of 89 gm and $55 \mathrm{gm}$ respectively. It possibly due to irrigation water with textile industry effluents with $35 \%$ concentration contain moderate fertility which result better nutrient supply for plant growth and root development. The percentage germination was found to be highest in treatment $\mathrm{T}_{1}$ with a value of $85 \%$. The result revealed that percentage germination, root and shoot dry weight, numbers of root branches/plants were found to be minimum under treatment $\mathrm{T}_{4}$ and $\mathrm{T}_{5}$ which, shows overall reduction in percentage germination and physiological parameters for both crops. Similar, results was reported by Gurfan khan et al., (2011) (Fig. 1).

Table.1 Percentage germination and physiological parameter like biomass and root development under different treatment

\begin{tabular}{|c|c|c|c|c|}
\hline Treatments & $\begin{array}{c}\text { Percentage } \\
\text { Germination }\end{array}$ & $\begin{array}{c}\text { Dry Weight of } \\
\text { Root } \\
(\mathbf{G m})\end{array}$ & $\begin{array}{c}\text { Dry Weight of } \\
\text { Shoot } \\
(\mathbf{G m})\end{array}$ & $\begin{array}{c}\text { Number of } \\
\text { Root Branch/ } \\
\text { Plant }\end{array}$ \\
\hline $\mathbf{T}_{\mathbf{1}}$ & 85 & 82 & 51 & 8 \\
\hline $\mathbf{T}_{\mathbf{2}}$ & 76 & 86 & 52 & 6 \\
\hline $\mathbf{T}_{\mathbf{3}}$ & 83 & 89 & 55 & 6 \\
\hline $\mathbf{T}_{\mathbf{4}}$ & 46 & 59 & 41 & 5 \\
\hline $\mathbf{T}_{\mathbf{5}}$ & 43 & 54 & 41 & 4 \\
\hline
\end{tabular}




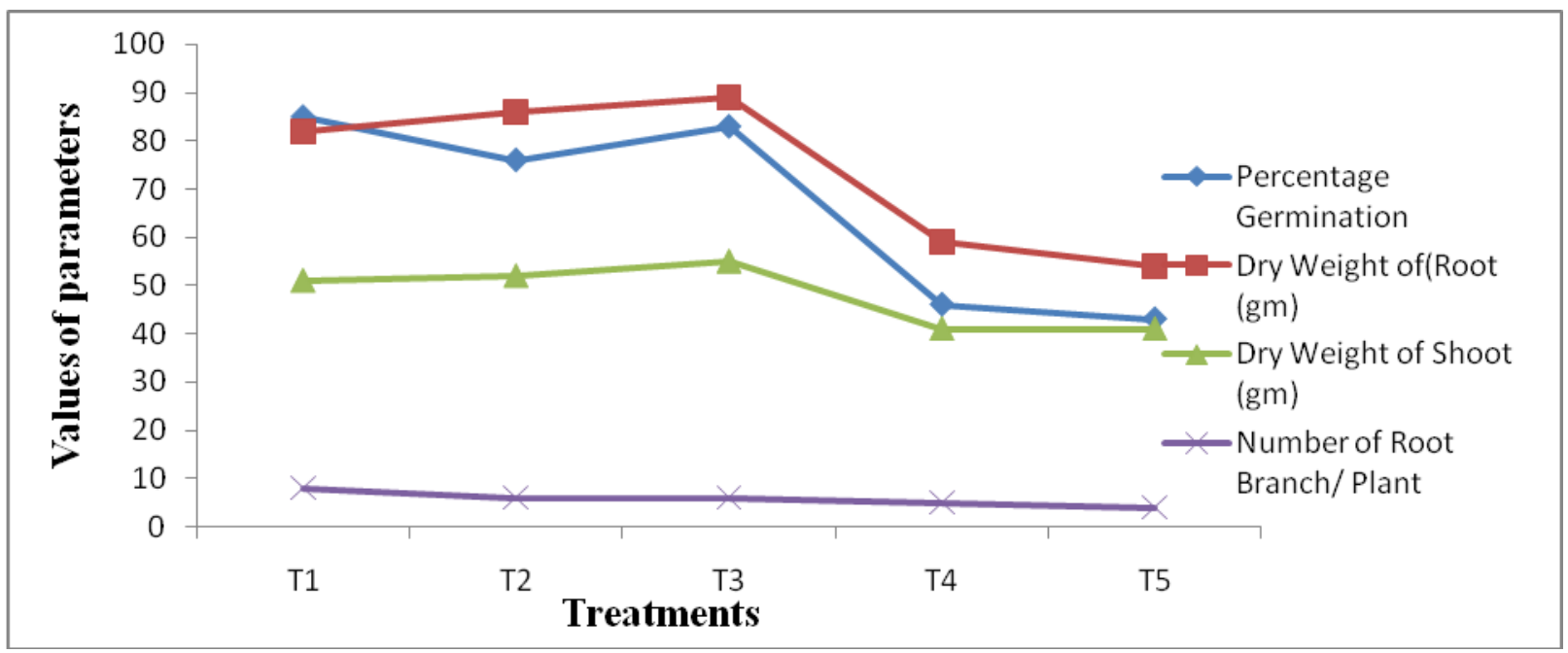

Fig.1 Performance parameters under different treatment

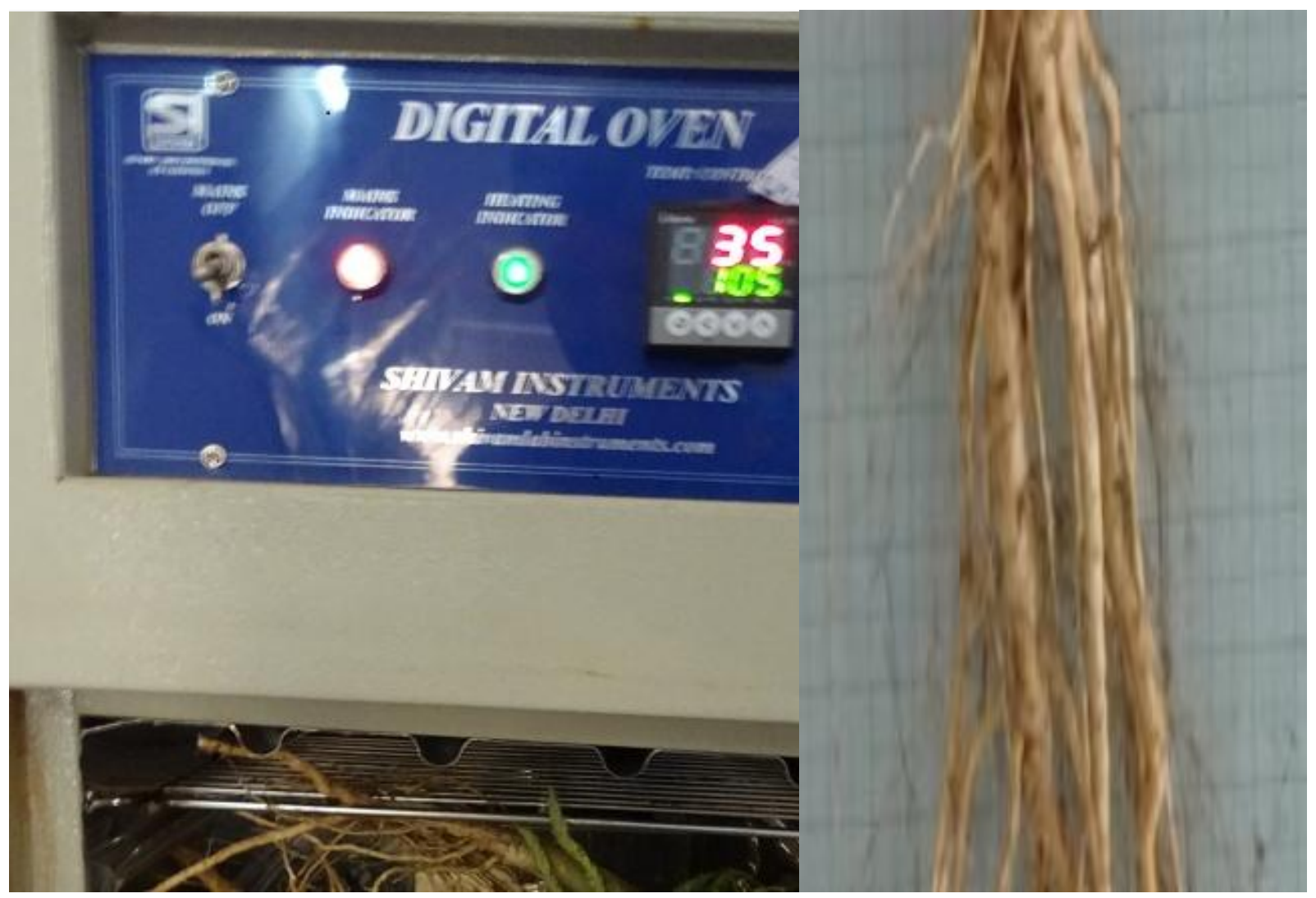

Plate.1 View of root and shoot during drying process

The textile industry effluent with high concentration effect germination percentage as well as physiological parameters of vegetable crop like tomato and brinjal.It was suggested that industrial waste water from textile industry could be utilized for irrigation purposes through drip irrigation after proper treatment and may contribute, at least in part towards solving the problem of disposal of textile effluent. 
The overall result concludes that textile industry effluent with moderate concentration up to $35 \%$ could be effectively used in vegetable production. The textile industry effluent with high concentration effect germination percentage as well as physiological parameters of vegetable crop like tomato and brinjal.

\section{References}

Bouman, B.A.M., Tuong, T.P. 2001. Field water management to save water and increase productivity in irrigated lowland rice. Agri Water Manage, 49, 11-30.

El-Rahman, G., Abd. 2009. Water Use Efficiency of Wheat under Drip Irrigation Systems at Al. Maghara Area, North Sinai, Egypt. American-Eurasian Journal Agri \& Envi Science, 5, 664 670 .

Choudhary, V.K. and Bhambri, M.C. 2012. Agro-Economic Potential of Capsicum with Drip Irrigation and
Christiansens, J.E. 1942. Irrigation by sprinkling. California Agricultural Experiment Station. Bulletin No. 670. Berkeley.

Debaeke, P. and Aboudrare, A. 2004. Adaptation of crop management to water-limited environments. European Journal of Agronomy21: 433-446.

Doorenbos J; Kassam A.H. 1979. Yield Response to Water. FAO Irrigation and Drainage Paper No. 33. FAO, Rome, Italy, pp. 193.

Guraf khan, M., Daniel, G.., Konjit, M., Thomas, A., Eyasur, S.S and Awoke, G. 2011. Impact of textile waste water on seed germination and physiological parameters of in pea, lentil and gram. Asian Journal of Plant Science.10: 269273.

Nadaffi, K.N., Jaaterzadeh, N., Mokhtari, M., Zakizadeh, B and Sakian, M.R. 2005. Effects of waste water stabilization pond effluent on agricultural crops. International Journal of Environment Science and Technology. 1: 273-277.

\section{How to cite this article:}

Manpreet Kaur, Vikas Sharma, Yadvendra Pal Singh and Paradkar, V.D. 2019. Effect of Textile Waste Water on Seed Germination and Some Physiological Parameters in Vegetable Crop under Drip Irrigation. Int.J.Curr.Microbiol.App.Sci. 8(07): 2006-2009. doi: https://doi.org/10.20546/ijcmas.2019.807.239 